\title{
Language Policy in University Education: the Case of Khakassia and Tyva
}

\author{
Tamara G. Borgoiakova* and \\ Aurika V. Guseinova \\ Katanov Khakass State University \\ 90 Lenin Str., Abakan, 655017, Russia
}

Received 28.02.2019, received in revised form 20.09.2019, accepted 04.10.2019

The paper deals with interface of macro- and micro-language policies in the language education of the southern Siberian republics of Tuvan and Khakassia, which includes Russian, foreign languages and indigenous languages, Tuvan and Khakass, which have the status of republican official languages. A comparative study of non-linguistic educational programs at various levels in Khakass State University and Tuva State University made it possible to evaluate the linguistic "weight" of undergraduate curricula and reveal a more obvious linguistic orientation in Tuvan State University. The undisputed leader among the foreign languages studied at two universities is English, German is the second. Sociolinguistic surveys of students of different ethnicity allowed establishing the levels of self-assessment of their language competence in foreign and native languages. Almost a third of respondents rate the quality of foreign language skills as unsatisfactory, which is associated with low level of school language education and minimal prospects for studying and working abroad. Self-assessment of the level of proficiency in ethnic languages is significantly higher - with only $18 \%$ of Khakass respondents not speaking their native language. However, the Tuvinian and Khakass languages included in the Atlas of Endangered Languages of UNESCO are practically not represented in the programs of university non-linguistic education. The introduction of mandatory USE in Russian and foreign languages, became a new challenge and threat to republican state languages and strengthens the role of micro-language planning and its agents at different levels.

Keywords: language planning, language policy, language education, Tyva, Khakassia.

Research area: philology.

Citation: Borgoiakova, T.G., Guseinova, A.V. (2019). Language policy in university education: the case of Khakassia and Tyva. J. Sib. Fed. Univ. Humanit. Soc. Sci., 12(10), 1796 1818. DOI: 10.17516/1997-1370-0489.

(C) Siberian Federal University. All rights reserved

* Corresponding author E-mail address: tamarabee@mail.ru ORCID: 0000-0001-9958-9086 (Borgoiakova); 0000-0001-9708-114X (Guseinova)

This work is licensed under a Creative Commons Attribution-NonCommercial 4.0 International License (CC BY-NC 4.0). 


\section{Introduction}

The interface of language planning and language policy (LPP) as a field of study is relatively young, having grown out of pragmatic concerns about solving language "problems" in decolonizing, multilingual polities during the second half of the $20^{\text {th }}$ century. Key ideologies and approaches of LPP scholarship development are connected with Fishman's vision of 'enduring debate in LPP research and practice' as 'competing ideologies of "one nation/one language" versus the value of individual and societal multilingualism' (McCarty, 2011: 5-6). This leads to the question of how this is played out in the context of different countries in response to the challenges that languages are facing due to the increasing forces of globalization and through interplay of macroand micro-planning (Baldauf, 1994; Kaplan, Baldauf, 1997; Spolsky, 2017).

In Russia much of LPP has been historically dominated by top-down policy defined by the federal government education agencies, often dictated by political and socioeconomic factors. Basics of the language policy in the meaning of a "document produced in the course of language management" (Spolsky, 2017: 4), are set forth in the federal legislation, including the Constitution of the Russian Federation and a special federal law 'On the languages of the peoples of the Russian Federation'. Regional language legislation also includes Constitutions and laws of the constituent subjects of the Russian Federation. Recent federal education reforms introduced since 2000 have had a major impact on language education. Changes to the federal law 'About Education' eliminated the regional component within the school curriculum, which contained minority languages education and was under regional control. The legal framework for the return to centralized control over curriculum was set through another federal law, changing the structure of State Educational Standards (SES). The Unified State Exam (USE) is implemented to ease the process of applying to higher educational institutions, to counteract corruption in the process of college admission, and to provide an objective measure of students' achievements. This standardized exam is mandatory to measure academic achievements not only in Russian and Mathematics but since 2020 - in a foreign language. No list of foreign languages for study is provided, but graduates of high school can choose among only four foreign languages: English, German, French and Spanish.

Present paper considers basic approaches to language education in two Siberian autonomies revealing the place and role of micro-language planning, including Russian, foreign languages and indigenous languages - Tuvan and Khakas on the one hand, and the influence of the macro agent, on the other. 


\section{Statement of the problem}

Linguistic assimilation, which posed a real threat to the majority of languages of the peoples of the Soviet Union, became one of the causes of its collapse in 1991. So it is no wonder that in the majority of the post-Soviet independent states the first laws to be enacted were language laws, giving the official state languages status to relevant titular languages. Russia was no exception: the federal law "On the Languages of the Peoples of the Russian Federation" was enacted in 1991, even before the country's Constitution of 1993 which declared all the languages of the peoples of Russia to be a national heritage protected by the state (Zakon o Iazykakh..., 1991). This was obviously directed to correcting the errors made in previous official language policy and to creating a legal mechanism for the protection of minority languages of Russia (Alpatov, 2010; Belikov, Krysin, 2001: 332-414; Borgoiakova, 2001: 8; Bowring, 2012; Felde, Kolmogorova, Zhuravel, 2017).

According to Article 6 of the mentioned Federal law 'On the languages of the peoples of the Russian Federation' a three level language hierarchy was established with Russian as a solo official language of the whole state, titular languages of the autonomous Republics and then - native languages of other peoples of Russia. It proclaims the competence of the Russian Federation to ensure functioning of Russian as the state language of the Russian Federation. And it is in the competence of the RF to assist the development of the state languages of the republics (Article 6, Zakon o Iazykakh). In 2005 a Federal Law 'On the State language of the Russian Federation' was adopted stating legal status of Russian as the only official (state) language of the whole country. According to Article 68 of the Constitution of the Russian Federation:

1. The Russian language shall be a state language on the whole territory of the Russian Federation.

2. The Republics shall have the right to establish their own state languages. In the bodies of state authority and local self-government, state institutions of the Republics they shall be used together with the state language of the Russian Federation.

More general formulations are suggested in the article for small in number indigenous languages: The Russian Federation shall guarantee to all of its peoples the right to preserve their native language and to create conditions for its study and development (Konstitutsiia Rossiiskoi Federatsii, 1993).

The efficacy of the implementation of the new Federal language legislation was different in the republics with high and low percentage of the titular nations. For example, in the Republic of Tatarstan Tatar language had become a compulsory 
subject of the school curricular for all school children irrespective to their ethnic origin (Garipov, Solnyshkina, 2006) and its visibility in different domains has become more obvious. In contrast, in the Republic of Khakassia the co-official status of the Khakass language does not make it obligatory as a language of instruction, or as a subject at school.

Much more responsibility in language policy and planning was transferred down to the regional authorities due to changes in the Federal Language Law made in 1998. The changes concerned the formulations prescribing the use of the state languages of the republics, which were changed to formulations of a permissive character (Articles $12,13,16,23)$. Adoption of minority languages maintenance programs seized to be obligatory on the federal level. Regional agents of language planning define now to much more extent the degree of minority languages support.

Alpatov points out that the current language policy-making, transferred from the centre to the regions, is carried out there in various ways: in some places local nationalism appears, in others excessive Russification. In general modern language policy in Russia is characterized by a 'lack of a unified thought-out policy without clear goals' (Alpatov, 2014: 20).

Analyses of current language policies in the Republics of Khakassia and Tyva, gives an illustration of the models of top-down macro policies and planning implementation on the regional level.

\section{Discussion}

\section{Language Policies in Khakassia and Tyva}

Republics of Khakassia and Tyva are situated in the South of Middle Siberia. They share common internal borders, while Tyva has an outer boundary with Mongolia. After joining Russia in 1707 territory of Khakassia was divided among different districts. In the Soviet times it was a part of the West Siberian region, and since 1934 - of the Krasnoyarsk Territory. Khakassia has acquired the current type of autonomy Republic of Khakassia in 1991.

People's Republic of Tanna Tuva and later the Tuvan People's Republic was a protectorate of Russia since 1921. It became a part of the Soviet Union in 1944 in a status of an autonomous Region (oblast), which was promoted to the autonomous republic in 1962. In 1991 it received present status and name - the Republic of Tyva.

Language Policies in Khakassia may be divided into two periods. The most positive first period was marked by adoption of the republican language law "On the 
Languages of the peoples of Khakassia" in 1992 which gave legal co-official status to the Khakass language. This official status was confirmed in the Constitution of Khakassia in 1995. In 1994 the Republican State Language Maintenance Program for the period of 1995-1999 was adopted and implemented. All this had a favorable effect on the language revitalization and increase of linguistic rights of the Khakass people. More children started to learn the mother tongue as a subject at school. Signs in the Khakass language appeared on the official buildings etc.

The second period was a direct response to the changes in the Federal language law of 1998. The Supreme Council (Verkhovnyj Sovet) of the Republic of Khakassia adopted Law 55 "Changes in the Republican Language Law on the Languages of the peoples of Khakassia", October, 2002 which limited social functions of the second official language of the Republic. For example:

- The right to use the Khakass language in the naming and renaming of the local territories, sites and villages was abolished leaving it for the federal state language;

- Article 18 in the new edition did not contain the right to use the second official language of the republic in films and video translation and dubbing;

- There was practically no mentioning of the use of the Khakass language in the domains of local economic life and business, as well as in the activities of local authorities and mass media, etc.

As a result of these politics there was an evident decrease in the number of schools and Khakass children learning their mother tongue (68\% in 2005 compared to $76 \%$ in 2000). Besides, a drop to about $\$ 6000$ per year from the budget of the republic to support language programs led to subsequent worsening of the situation with regard to availability of textbooks and other teaching materials for the mother tongue teaching (instruction) (Borgoiakova, 2005).

International, national and regional conferences organized in the Katanov Khakass State University gave an additional impulse to lingua-ecological activities, to learning more from the international experience in the field. The Resolution adopted at the first International Conference "Development of Indigenous Siberian Languages and Cultures in a Changing Russia" (2005) drew attention to the negative tendencies in the Khakass language legislation in part of the Khakass language maintenance. It was sent to the Government authorities in Khakassia and to the Representative of the President of Russia in Siberian Federal Okrug. In response to this, changes were adopted in 2008 to the republican language legislation abolishing most obvious limitations on the use of Khakass and other minority languages (Borgoiakova, 2015a). 
Unlike neighboring Khakassia, the demography of Tyva supports high level of Tuvan language vitality. Tuvans have always comprised a majority of the population in their autonomy with compact settlement and no railway connection with other parts of Russia. These factors determined the high level of intergenerational transmission of the Tuvan language, preserving very good command of the mother tongue among majority of country children.

The law "On languages in the Republic of Tyva" includes a preamble defining the language as an essential component and a carrier of spiritual culture as the main form of manifestation of ethnic and personal identity. It emphasizes that the law is aimed at creating conditions for 'equal and original development of Tuvan and Russian languages', and the republic 'contributes to the development of minority languages, bilingualism and multilingualism'. State languages of the Republic of Tyva are Tuvan and Russian (Article 2). In general, the law provides the use of the two official languages in 12 cases out of 15 referred to in the text of the law.

Legislation of both republics contains a citing from the federal law in Education, saying that the use of languages in education includes the right to receive basic general education in the native language, as well as the choice of the language within the possibilities offered by the education system. The right to education in the mother tongue is achieved through creating the necessary number of corresponding educational institutions, classes, groups, as well as creating conditions for their functioning. However, according to Bavuu-Syuryun, the question of preserving the Tuvan language becomes urgent due to the fact that 'much of the Tuvan language rights are declarative'. A 'simple declaration of the equal use of languages in various spheres of society, without an adequate software, the relevant research, staffing, funding from the budgets of different levels, had not given the expected positive results' (BavuuSyuryun, 2010: 62).

According to UNESCO Atlas of the World's endangered Languages Tuvan belongs to the first group of vulnerable languages, where most children speak the language, but it may be restricted to certain domains; Khakass is in the next group of definitely endangered languages, where children no longer learn the language as mother tongue in the home (Moseley, 2010).

This means that language policies in the two republics should have common and specific features in language planning in the language ecology context. This will be confirmed in this paper through the data of current surveys and analyses of language legislation and its implementation on different educational levels, Universities included. 


\section{Language Loyalties}

The last four Russian censuses provide informative data of language loyalties and the speed of the language shift among the two neighboring Siberian indigenous peoples. It is necessary to mention though that census questions concerning languages were put in different way. Respondents were to name their mother tongue in 1979 and 1989 which is a definite marker of language loyalties level and at the same time it does not always reflect the level of language competence (see Belikov, Krysin, 2001). In 2002 and 2010 censuses the question concerned the languages people speak (Fig. 1).

But the next dimension of language loyalties - language attitudes or the feelings people have about their own language (Crystal, 1992) - has positive dynamics. According to our sociolinguistic surveys in Khakassia, there was evident growth in the proportion of Khakass respondents $(\mathrm{KhR})$ who express readiness to raise their children bilingual and to participate in grass root activities in support of the mother tongue (Table 1).

There is evident difference in the loyalties towards Khakass language with much more positive feelings on the side of the KhR compared to Russian ones. For example, according to the surveys in 2012, $96 \%$ of the KhR compared to $21.5 \%$ of Russian respondent (RR) would like their children to learn the Khakass language; $95 \%$ of the $\mathrm{KhR}$ and $18 \%$ of RR would like to start learning the Khakass language, $87 \%$ of the KhR and $76 \%$ of RR think that Khakass children should study their mother tongue. Thus, in spite of the negative tendencies in language loyalties of the Khakass people

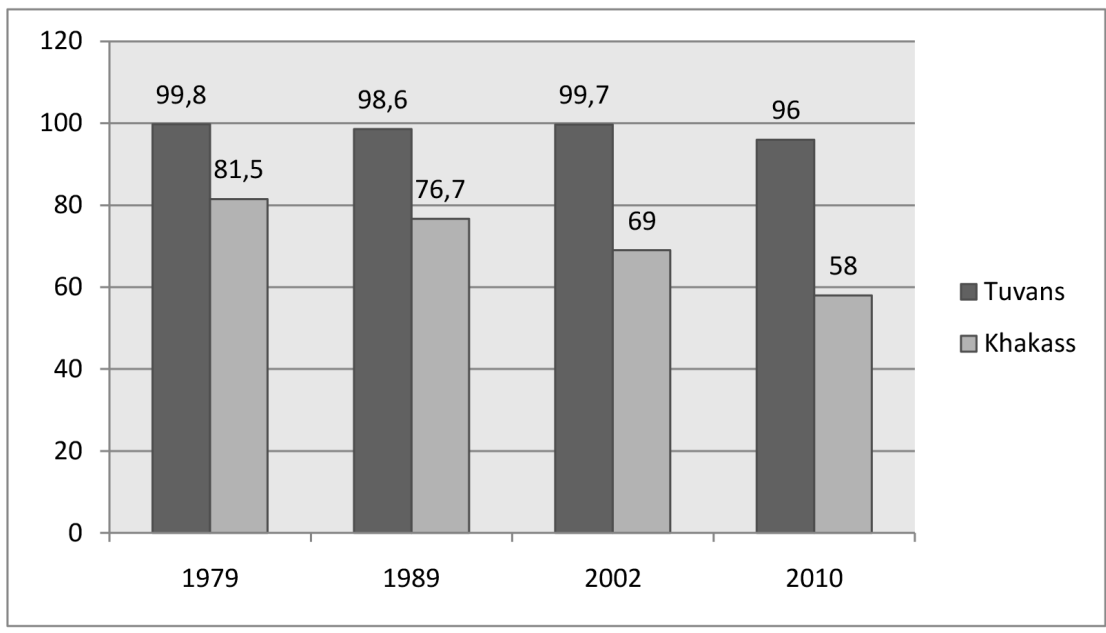

Fig. 1. Language Loyalties of Siberian Indigenous Peoples 
towards their mother tongue reflected in the census data, the results of the current surveys show that emotional attitudes to the mother tongue continue to be positive. At the same time, the attitude of the dominant Russians in general is not hostile, which is important in the supportive top down and grass-root language planning efforts (Borgoiakova, Guseinova, 2012; Borgoiakova, Guseinova, 2017).

Table 1. Language attitudes of the Khakass respondents $(2002,2012)$

\begin{tabular}{|l|c|c|}
\hline \multirow{2}{*}{ Statements/Questions } & \multicolumn{2}{c|}{ KhR (\%) } \\
\cline { 2 - 3 } & 2002 & 2012 \\
\hline I think it is necessary to know the Mother tongue & 89 & 99 \\
\hline It it necessary to teach the Khakass language at school & 89 & 96 \\
\hline I want my children to know the Khakass language & 87 & 96 \\
\hline $\begin{array}{l}\text { I am ready to take part in the activities in the support of the Khakass } \\
\text { language }\end{array}$ & 85 & 97 \\
\hline
\end{tabular}

In 2012 and 2013 surveys with the participation of 153 Khakass and 136 Tuvan respondents (TR) respectively were conducted and in 2013 additional 150 Khakass respondents $(\mathrm{KhR})$ were involved. Some results of these surveys represented in Table 2 show that the level of recognizing Tuvan as the mother tongue is high (91\%). The vast majority of the TR are fluent in their native language, know songs in their native language, communication with parents and the older generation is mostly in the native language. $100 \%$ of the respondents speak Russian, but only $30 \%$ evaluate their level of competence as high, while the majority names it partial. TR often use bilingual strategy in communication with friends and colleagues. $100 \%$ want to have Tuvan at school and their children to know it.

As is seen in the table below, the proportion of recognizing Khakass as the mother tongue is about $50 \%$. All of those who used Khakass until 6 years old (54\%) report their level of language competence as high. Native language use prevails only in the areas of informal communication with older relatives in the family and with friends. In situations of official communication or communication with colleagues bilingual communication strategy dominates. All KhR are fluent in Russian.

More than half of respondents said their mother tongue to be the most important indicator of ethnicity, believing that you cannot be Khakass, not knowing the Khakass language. Slightly less than half of the respondents think that one can be Khakass 
not knowing the native language and name other indicators of ethnic identification. TR consider native language to be much more important for their ethnic identity.

Table 2. KhR and TR languages use and attitudes in a comparative perspective (according to the sociolinguistic survey 2013) (\%)

\begin{tabular}{|l|c|c|}
\hline \multicolumn{1}{|c|}{ Statements } & TR & KhR \\
\hline Accept the ethnic language as their mother tongue & 91 & 50,5 \\
\hline It is necessary to know the mother tongue & 100 & 98 \\
\hline The competence in the mother tongue is: good & 94 & 54 \\
satisfactory & 6 & 28 \\
low (zero) & - & 18 \\
\hline The competence in Russian is: good & 30 & 100 \\
satisfactory & 70 & - \\
\hline Studied the mother tongue at school & 97 & 65 \\
\hline Used (until 6 years old): & & \\
mother tongue & 83 & 54 \\
both mother tongue and Russian & 17 & 11 \\
Russian & - & 35 \\
\hline Know songs in the native language & 97 & 71 \\
\hline Mother tongue should be present at school & 100 & 100 \\
\hline Want their children to know their mother tongue & 100 & 98 \\
\hline Ready to contribute to the preservation of the native language & 89 & 92 \\
\hline The future of the mother tongue is threatened & 62 & 89 \\
\hline Communication with parents: in the mother tongue & 80 & 37 \\
both in the mother tongue and in Russian & 20 & 40 \\
\hline Communication with grandparents: in the mother tongue & 92 & 47 \\
both in the mother tongue and in Russian & 8 & 33 \\
\hline Socializing with friends: in the mother tongue & 55 & 4,5 \\
both in the mother tongue and in Russian & 45 & 59 \\
\hline Communication with colleagues: in the mother tongue & 37 & 2,3 \\
in the native language and in Russian & 42 & 51 \\
\hline Contacting public institutions: in the mother tongue & 79 & - \\
both in the mother tongue and in Russian & 29 & 46 \\
\hline It is possible to be a representative of the ethnic group without the & & \\
knowledge of the mother tongue & & 22 \\
\hline & & \\
\hline
\end{tabular}

\section{Language Education in Russia}

According to 2010 census data, less than eight percent (7.76\%) of the population of the Russian Federation had some competence in foreign languages with English at the top, making seven and a half million people (5.48 \%). Then German follows (more 
than two million or $1.5 \%$ ), French (616 thousand), Spanish (152 thousand), Turkish (146 thousand), Italian (83 thousand), Chinese (70 thousand). (Federal state statistics service, 2010).

High school curriculum in Russia can be defined as linguistically oriented. The SES of primary, basic and secondary education includes the impressive philological units with the requirements for studying courses of Russian language, regional mother tongues and foreign languages. One of the main objectives on the primary level of education is 'the formation of the initial ideas about the unity and linguistic and cultural diversity of Russia, of language as the basis of national identity'. It is stated in the SES that 'curricula provides teaching and learning of the state language of the Russian Federation, the possibility of teaching and learning the official languages of the republics of the Russian Federation and other native languages of the peoples of Russia' (Federal'nye gosudarstvennye obrazovatel'nye standarty, 2009). As Goryacheva notes, of foreign languages studied in high schools, English takes the first place with $79 \%$ of all pupils, German is second (16.6\%), and French is in third place (4\%). Among other foreign languages, studied by $0.6 \%$ of pupils, Italian is the leader, while Turkish and Arabic lead non-European languages (Goryacheva, 2010).

SES contains a lot of references to the need to preserve and promote cultural diversity and linguistic heritage of the multinational people of the Russian Federation. The standards are aimed at ensuring the rights of citizens to study their native language, recognize spiritual and cultural values of the polyethnic people of Russia. However, in the educational standards of higher education no mentioning of ethno cultural and linguistic heritage is preserved. SES of the undergraduate programs state that a foreign language belongs to the cycle of mandatory humanitarian, social and economic disciplines, alongside with history and philosophy. Most Undergraduate programs point out that graduates should acquire communicative and social skills in Russian and foreign languages. The only exception among non-linguistic undergraduate programs is the educational standard in "Journalism". The program contemplates cultural competence of "fluency norms and means of expression" in Russian and native languages. This special reference to the native languages is related to the specific features of the ethno regional journalism.

\section{Language Planning in Universities of Khakassia and Tyva}

The first state institutions of higher education in the form of pedagogical institutes training teachers were established in Khakassia and in Tyva in 1938 and in 1952 
respectfully. These institutions were reorganized into the Katanov Khakass State University (the Khakass State University - KhSU) and the Tuva State University (hereinafter TuvSU) in 1994 and in 1995.

The analysis of language policy of these Universities showed that there is no officially accepted written document describing that policy. But principals and documentation relating to language policy are integrated in various University documents. First of all, both Universities Charts underline that the admission process may be conducted in Russian or in the state language of the corresponding Republic of the Russian Federation. The educational process at the university is conducted in the state language of the Russian Federation — Russian. By decision of the Academic Council of the University (Uchenyi Sovet) classes can be conducted in the languages of the peoples of the Russian Federation and in foreign languages.

In addition, in the list of priority directions of research of $\mathrm{KhSU}$ two philological directions are represented: "Studies of the modern communicative space in the global and regional contexts" and "Languages, history and cultures of the indigenous peoples of southern Siberia in the dynamics of polyethnic space".

At the beginning of higher education in Khakassia in 1939 German was the only foreign language studied by students. With the establishment of the faculty of foreign languages in 1963 English and French were added to the curriculum of future teachers of foreign languages and to other programs (Bezrukova, 2014). During recent years acquisition of English, German, French, Spanish and Chinese both as the first languages or the second ones were suggested in $\mathrm{KhSU}$ at the undergraduate programs in Linguistics (English and German languages) with educational profiles "Translation and Translation studies", "Theory and methodology of teaching foreign languages and cultures" and two graduate programs in English and German Philology: "Foreign language and literature" and "English language and intercultural communication". There are also two programs of postgraduate studies - "Germanic languages (English)" and "Theory of language" (Dorina, 2014; Kutyaeva, 2014).

The Department of foreign languages and methods of teaching offers practical courses of English, German, French, Spanish and Chinese languages, business courses of English, German, French, Spanish for improving communication skills in business, language courses for schoolchildren, as well as giving assistance in preparing for the TOEFL. In general, there are also additional courses training Chinese, Polish, Turkish.

Institutes and Colleges of the KhSU provide 101 undergraduate and graduate programs and programs of post graduate education and the TuvSU -73 . The 
information on the number of basic educational programs, taken from the official sites of these Universities is represented in Table 3.

Language education in these Universities consists of studying foreign languages, the Russian language, indigenous languages (Khakass and Tuvan). Special undergraduate programs aimed at training high school teachers in Khakass and Tuvan languages have become traditional. They started with the first intake of students in 1938 and in 1952 respectively in both Universities. Lately a graduate and a post graduate program oriented to research in these languages were introduced in each University.

In this paper we concentrate our attention on undergraduate Universities programs where students do not specialize in languages. We mostly relate to such issues as: what foreign languages are offered and used as media of instruction; how majority Russian and minority Khakass and Tuvan are represented in these Institutions and educational standards of federal and regional level. The next Table 4 gives details of the comparative quantitative data.

Table 3. KhSU and TuvSU higher education programs

\begin{tabular}{|l|c|c|}
\hline \multicolumn{1}{|c|}{ Programs and students number } & KhSU & TuvSU \\
\hline Undergraduate programs (4-5 years) & 55 & 69 \\
\hline Graduate programs & 25 & 3 \\
\hline Post graduate programs & 41 & 46 \\
\hline $\begin{array}{l}\text { Number of students on the undergraduate (4-5 years) } \\
\text { and graduate programs }\end{array}$ & 6269 & 4625 \\
\hline
\end{tabular}

Table 4. Comparative data on Russian and foreign languages courses in non-language and not pedagogical undergraduate programs in KhSU and TuvSU

\begin{tabular}{|l|c|c|}
\hline & KhSU & TuvSU \\
\hline Number of credits for studying Russian & $1-4$ & $2-5$ \\
\hline Number of programs suggesting optional courses of Russian & 7 & 1 \\
\hline Number of credits for studying foreign language(s) & $3-34$ & $6-54$ \\
\hline Number of programs suggesting optional courses of foreign language & 4 & 7 \\
\hline
\end{tabular}

The study of Russian is compulsory for all students at the undergraduate and specialists levels. The classes are usually called "Russian language and culture of 
speech" or "Russian", "Culture of speech", "Russian in business communication" or "Speech communication and business culture". The usual number of hours for them varies between 2 and 3 credits. Future teachers of different profiles also study the course "Pedagogical rhetoric" and future lawyers - "Judicial rhetoric". All this testifies to the fact that students have an opportunity to obtain the necessary linguistic component of University education.

The biggest number of hours for acquisition of a foreign language among nonlanguage programs in KhSU is a program in 'History'. Future historians study the first foreign language during six semesters (18 credits), and in addition, they learn a second foreign language (13,5 credits) during four semesters. A course of Latin is also compulsory for one semester ( 2 credits). Large amount of hours devoted to the study of linguistic disciplines, as well as a variety of language courses, makes this program the most "linguistically oriented" among all other non-linguistic programs of the University.

Much attention is given to the study of a foreign language in the Institute of Economics and Management. Thus, learning a foreign language in the "Sociology" program, gives 11 credits. Curriculum of the program "State and municipal management" involves two subjects "Foreign Language" and "Foreign Language in the professional field" (7 credits each). However, graduate program "Management (regional government)" curriculum also includes "Special course for foreign language" and "Foreign language in professional activity" with 2 credits each.

The smallest course "Foreign Language" is planned in the Agricultural Institute. For instance, the undergraduate program "Agronomy" involves the study of a foreign language in the amount of three credits. In general, a usual standard number of hours for the course "Foreign Language" in KhSU is 5-6 credits, although the scale at the undergraduate level is, as was stated above, 3-19 credits.

A positive experience of using a foreign language (English) as a means of instruction in the curricula of some technical programs in KhSU should be noted. As an example a program in "Applied Informatics in Economics" should be mentioned, where students are offered an optional course "Information Technology (in English)" and "Technical English" (3 credits each). The curriculum of the graduate program "Computer Science and Engineering" also offers a course on "Modern Problems of Information Society (in English)" (2 credits). Such programs, offering some classes in English are a kind of exception yet. However, their introduction first for IT-specialists is a good way to raise their level of professional training. 
In TuvSU the number of hours to study the Russian language is more than in KhSU. This course is usually divided into two sub-courses with 2 credits each. Largest number of hours among non-language and non-teaching programs is 5 credits for undergraduate programs in "Agriculture" and "Gardening".

The amount of time devoted to studying foreign languages in TuvSU is also greater than in the KhSU. The minimum number of credits starts from 6 for the following undergraduate programs: "Construction", "Psychology", "Economy", "Gardening" and some others. The next group of programs suggests 8 credits for the course of foreign language: "Geography", "Ecology and Nature". The highest amount of credits is included in the curriculum of the program "Clerical work and Information Science" — 14.

In the undergraduate program "History" in TuvSU the standard number of 6 credits for studying foreign languages is established. However, this program with additional training in the profiles of "Historical Science 'and' History, Profile Archeology" suggests 17 credits for the course of foreign language and 4 - for a second foreign language. Probably, such a serious attention to foreign languages is paid due to the specifics of the profession, involving analysis of multiple sources in foreign languages.

More time of foreign languages training is suggested for the undergraduate program "Foreign Regions Studies", the profile "Asian Studies (Central Asia)." Besides the course "Foreign Language" with standard 6 credits, there are additional classes of English (18 credits), Mongolian language (27 credits), Old Mongolian language (3 credits). In addition, the program curriculum provides credits for translation practice. The number of credits for learning a foreign language in total is 54, which is the maximum among the non-language undergraduate programs in TuvSU.

Both Tyva and Khakassia have good tourist potential due to their ethno cultural heritage and history. And both Universities suggest undergraduate program "Tourism". The amount of credits predicted there for the study of two foreign languages is the following: in TuvSU — 19 credits and additional course "Business Foreign Language" - 3 credits. And for educational tourist practice in foreign language 3 credits. Besides, 5 credits are predicted in the curriculum for the course "Russian language and culture of speech" and 2 for "Linguistics".

The study of Khakass and Tuvan language is offered in the curricula of this program neither in $\mathrm{KhSU}$ or TuvSU, even as an elective. In general, the presence of regional indigenous languages in the educational space of these universities is limited. Courses in or on these languages are not usually included in the curriculum of non- 
language Programs. The only exception found was an elective course of "Business Tuvan language" in the curriculum of the undergraduate program 'Clerical work and Information Science' in TuvSU. Tuvan language is also represented on some linguistic and pedagogical programs, which, however, are not directly related to its studies and teaching. Thus, in TuvSU the program "Teachers Training" (profile "Philological Education") suggests optional classes "Tuvan language". And all students of the Philology department have both Russian language and Tuvan language Workshops.

But both universities suggest optional courses related to the historical and cultural heritage of the region: "The history of Tuva and Turks" in TuvSU and "Archeology of Southern Siberia" and "The Ancient Art of Khakassia" in KhSU.

Besides, both Universities provide special programs suggesting graduate and post graduate programs "Languages of the peoples of the Russian Federation" (Khakass and Tuvan languages respectively. Each academic year undergraduate Khakass and Tuvan teachers training programs enroll a group of freshmen. These programs are bilingual where Russian and Khakass/Tuvan are the languages of instruction.

Revealed common features and peculiarities of micro-language planning in two Universities show correlation between the federal language law, SES, global, national and regional languages hierarchies. Analyses of their language planning show that foreign languages and first of all English are still used as subjects of study with very few attempts (revealed only in $\mathrm{KhSU}$ ) to wider use of it as a language of instruction and as a language of research.

\section{Results of Student's response in surveys}

Study of language planning in the south Siberian universities included surveys among 409 students (223 in KhSU and 186 in TuvSU). Ethnic Tuvans made $90 \%$ of the respondents of TuvSU and among KhSU respondents there were $86.5 \%$ of ethnic Russians, $8 \%$ - of ethic Khakass, $2.2 \%$ of Tuvans. The results are presented in several tables to follow.

As is seen from Table 5, the rating of foreign languages which students learnt in high schools of Khakassia and Tyva is practically identical: almost ninety percent of pupils in both republics learn English, a little more than $10 \%$ - German and a very small amount of French acquisition. Besides, a small portion of respondents reported learning two foreign languages at high school. But the situation is different at the University level. The growth of the number of students studying German language in $\mathrm{KhSU}$, compared to the number of such students at high school, can be explained 
by the answers of the respondents from the History department, where they learn both English and German. This data correlate with the information of the Head of the Department of Foreign Languages and Methods of their Teaching in KhSU, who pointed out that representation of English and German at the university is distributed in proportions, roughly equal to $90 / 10$ percent of students accordingly.

Table 5. The rating of foreign languages students learnt at high school and University level (\%)

\begin{tabular}{|l|c|c|c|c|}
\hline \multirow{2}{*}{} & \multicolumn{2}{|c|}{$\begin{array}{c}\text { Foreign language acquisition } \\
\text { in high school }\end{array}$} & \multicolumn{2}{c|}{$\begin{array}{c}\text { Foreign language acquisition } \\
\text { at the Universities }\end{array}$} \\
\cline { 2 - 5 } & KhSU & TuvSU & KhSU & TuvSU \\
\hline English & 87,9 & 87,6 & 85,6 & 73,1 \\
\hline German & 13,9 & 12,3 & 17 & 32,2 \\
\hline French & 2,2 & 4,3 & - & 2,1 \\
\hline
\end{tabular}

In the TuvSU much more visible growth of students learning German has taken place. This happened because some students who learned English at high school turned to German at the University. The analysis of survey data revealed that this is true mostly for the students of the program "Primary education". The reason why some of them fell into the English group, and some - into German, is not quite clear. Sometimes it depends on the number of teachers of these two languages at the University department of foreign languages, where German teachers nowadays often suffer from the lack of load.

KhSU students also made comments about other available forms of learning foreign languages. It turned out that though language courses and tutoring were not popular, such additional classes gave opportunities to learn not only English and (or) German but other languages too. But the number of students who visited French, Spanish, Chinese, Japanese, Polish and Khakass language courses was small. Self-study of foreign languages is more popular. German is in the top here with $33 \%$ of respondents who made efforts to learn it by themselves. Then $26 \%$ of students reported English, $2 \%$ - Spanish and $1 \%$ - Italian and all the previously mentioned languages.

According to the survey, self-esteemed language competence level is almost equal in the two Universities. The vast majority of students rated their knowledge of a foreign language as satisfactory (Table 6).

More than a quarter of respondents in $\mathrm{KhSU}(26 \%)$ and more than a third in TuvSU (31.8\%) rated their knowledge of a foreign language as unsatisfactory. And 
only $5 \%$ and $5.7 \%$ of respondents gave high self-esteem to their foreign language proficiency. Most University language educators interviewed in KhSU pointed out low level of foreign language proficiency of students on admission. The small amount of classes at the University level cannot save the situation as they have to start again from the alphabetic elementary level. This may be correlated with low expectations of students for the use of foreign languages for work in Russia or abroad.

The next question of the survey allowed to determine what foreign languages students would like to be fluent in. They named seven languages, which are rated in Table 8.

Table 6. Students' self-esteem of foreign languages proficiency (\%)

\begin{tabular}{|l|c|c|}
\hline \multicolumn{1}{|c|}{ Level of self-assessment } & KhSU & TuvSU \\
\hline High (free communication) & 5 & 5,7 \\
\hline Satisfactory (difficulties in communication) & 69 & 62,5 \\
\hline Unsatisfactorily (inability to use language in communication) & 26 & 31,8 \\
\hline
\end{tabular}

Table 7. The spheres of foreign languages use (\%)

\begin{tabular}{|c|c|c|c|c|c|c|c|}
\hline & $\begin{array}{c}\text { Work/ } \\
\text { study } \\
\text { abroad }\end{array}$ & $\begin{array}{c}\text { Work in } \\
\text { Russia }\end{array}$ & Tourism & $\begin{array}{c}\text { Communication } \\
\text { abroad } \\
\text { with foreigners } \\
\text { in Russia }\end{array}$ & $\begin{array}{c}\text { Communication } \\
\text { with colleagues/ } \\
\text { relatives } \\
\text { in Russia }\end{array}$ & $\begin{array}{c}\text { Cultural } \\
\text { purposes, } \\
\text { books, } \\
\text { movies }\end{array}$ & $\begin{array}{c}\text { Professional } \\
\text { information }\end{array}$ \\
\hline English & 16 & 8 & 18 & 25 & 7 & 65 & 29 \\
\hline German & 15 & 7 & 11 & 7 & 4 & 70 & 11 \\
\hline
\end{tabular}

Table 8. Foreign languages students would like to be fluent in (\%)

\begin{tabular}{|l|c|c|}
\hline & KhSU & TuvSU \\
\hline English & 81 & 83 \\
\hline French & 24 & 13 \\
\hline German & 18 & 13 \\
\hline Spanish & 11,6 & 1,6 \\
\hline Chinese & 10 & 25,8 \\
\hline Korean & - & 7 \\
\hline Mongolian & - & 3,7 \\
\hline
\end{tabular}


The table shows the differences and similarities in the language preferences of students in universities of neighboring Siberian regions. A predictable result for English to be at the top of the rating was received with practically equal result in both Universities. An unexpected second rate came out for French (24\%) overcoming German (18\%) in KhSU, while these languages got the same $13 \%$ in the TuvSU. Spanish was one of the languages taught at the KhSU department of foreign languages for more than 10 years. This may explain its higher popularity in KhSU (11.6\%) compared to its $1.6 \%$ in TuvSU. But Chinese, the most attractive language, in which TuvSU students want to be fluent in, is rating the second after English with $25.8 \%$, and in the KhSU this figure does not exceed $10 \%$. Two more Asian languages - Korean and Mongolian overcome Spanish in the sympathies of Tuvan students, while they were not mentioned in KhSU. Revealed differences in the list of language preferences can be also explained due to peculiarities of the geographical position of the Republic of Tyva, which is located in the center of Asia, borders on Mongolia and is closer to China. It should be also noted that there were other single mentioning of the desire of students to be fluent in Japanese and Italian. Only KhSU respondents named Polish, Serbian, Portuguese, and TuvSU respondents — Tadjik and Turkish.

The next question asked to explain why the surveyed wished to be fluent in the chosen foreign languages. As can be seen from the Table 9, the most compelling reason for learning foreign languages for the majority of students of $\mathrm{KhSU}$ is the need to use them when traveling (57\%), for students of TuvSU — an opportunity to study/work abroad (39\%). The second leading cause in both Universities is the status of a global language. Equally less popular (19\%) is an ability to make "a successful career" which indicates that foreign languages fluency does not seem to influence career growth in this Siberian region.

Table 9. Reasons of the desire to be fluent in a foreign language (\%)

\begin{tabular}{|l|c|c|}
\hline & KhSU & TuvSU \\
\hline Language of the global status & 52 & 30 \\
\hline An opportunity to study / work abroad & 37 & 39 \\
\hline An ability to make a successful career & 19 & 19 \\
\hline A sign of a civilized man & 21 & 13 \\
\hline Travelling & 57 & 29 \\
\hline
\end{tabular}


Information about the spheres in which KhSU students have used the two leading foreign languages (percentage is calculated from the number of those who studied it at the university) is presented in Table 7. Both English and German are used most of all for cultural purposes, where German has surpassed English by $5 \%$. English is used for getting professional information almost by a third of the respondents, and by a quarter of them - in communication with foreigners in Russia. It is also ahead of German in foreign tourism and in all other fields represented in the table.

Additionally, respondents used French, Spanish, Polish, Italian and Japanese languages in foreign travel and for cultural purposes. Unfortunately, the results of the survey about spheres of using foreign languages by TuvSU students turned out to be invalid due to their misunderstanding some questions - we plan to continue the research there. However, it was revealed that other European languages, besides English and German, are less popular in comparison with Asian languages among Tuvan students. Many of them noted that they actively use Chinese, Korean and Mongolian languages in all the discussed spheres (except work in Russia).

Thus summing up the results of the surveys we can conclude that English is the leading foreign language studied in high school (87\%) and in the Universities of both Republics (85-73 \%) while German is in the top among languages of self-study (33 \%) in KhSU. Though the majority (more than $60 \%$ ) of the respondents rated their knowledge of foreign languages as satisfactory (more than $60 \%$ ), they admit the value of better proficiency in them. The majority of respondents in both Universities (more than $80 \%$ ) would like to be fluent in English and in four other foreign languages of global status, opening doors to travelling, work or studies abroad and to a successful career.

\section{Conclusion}

Language planning in Russia has always been the tool for implementation of the state language policy. Its basics are legalized in the Constitution and special language oriented laws on the federal and regional levels. The macro agent of LPP in the face of federal government works out SES which is mandatory on all the levels of education throughout the country.

Despite absence of any officially accepted written document designing language policy of the micro agents, principals and documentation relating to LPP are integrated in various University documents. In both Universities the admission and educational process may be conducted in the state language of the Russian Federation. By decision 
of the Academic Council of the University (Uchenyi Sovet) classes can be conducted in the languages of the peoples of the Russian Federation and in foreign languages. This right is exercised in conducting classes both in Russian and Khakass/Tuvan languages in the undergraduate programs where future teachers of these languages are trained. The rating of foreign languages which students learnt in high schools of Khakassia and Tyva is practically identical: almost ninety percent of pupils in both republics learn English, a little more than $10 \%$ - German and a very small amount of French acquisition. This data mostly correlate with the representation of English and German at the university, roughly equal to $90 / 10$ percent of students accordingly. Self-esteemed language competence level is almost equal in the two Universities.

The essential difference of the sociolinguistic situations in neighboring Khakassia and Tuva developed due to extra linguistic factors - demographic dominance of the native population, shorter period of language contact, etc. The contrasting demographic power of the two state languages of the republics - Khakass and Tuvan, defines differences in their status in high school education, level of language competence, bilingual communicative strategies and intergenerational transmission at home. Federal education reforms with the introduction of mandatory USE in Russian and foreign languages, put republican state languages aside and have become a new common challenge and threat to still positive attitudes to them, reshaping and strengthening the role of micro-language planning and its agents at different levels.

\section{References}

Alpatov, V.M. (2010). Dvadtsat' let spustia [After twenty years]. In Vladimir Vinogradov and Vida Mikhalchenko (eds), Iazyk i obshchestvo v sovremennoi Rossii $i$ drugikh stranakh [Language and Society in Present - Day Russia and Other Countries]. Moscow, 1-5.

Alpatov, V.M. (2014). Iazykovaia politika v Rossii i v mire [Language policy in the Russian Federation and in the world]. In Aisa Bitkeeva and Vida Mikhalchenko (eds), Iazykovaia politika $i$ iazykovye konflikty $v$ sovremennom mire [Language policy and language conflicts in contemporary world]. Moscow, 11-24.

Baldauf, R.B. (1994). "Unplanned" language policy and planning. In Annual Review of Applied Linguistics, 14, 82-89.

Bavuu-Syuryun, M. (2010). Tuvinskii iazyk na sovremennom etape: obrazovatel'nyi aspekt [Tuvan language on modern stage: educational aspect]. In Novye issledovaniia Tuvy [The new research of Tuva], 3, 57-71. 
Belikov, V.I., Krysin, L.P. (2001). Sotsiolingvistika [Sociolinguistics]. Moscow, Rossiiskii gosudarstvennyi gumanitarnyi universitet, 439 p.

Bezrukova, A.V. (2014). Prepodavanie inostrannykh iazykov v Khakasskom gosudarstvennom universitete im. N.F. Katanova [Teaching foreign languages in the Katanov Khakass State University]. In Vestnik Khakasskogo gosudarstvennogo universiteta im. N.F. Katanova [Bulletin of Katanov Khakass State University], 7, 137-139.

Borgoiakova, T.G. (2001). Minoritarnye iazyki: problemy sokhraneniia i razvitiia [Minority languages: problems of preservation and development]. Abakan, Izdatelstvo Khakasskogo gosudarstvennogo universiteta im. N. F. Katanova, 160 p.

Borgoiakova, T.G. (2005). Razvitie sotsial'nykh funktsii khakasskogo iazyka $\mathrm{v}$ kontekste sovremennogo iazykovogo zakonodatel'stva [Development of social functions of the Khakass language in the context of modern language legislation]. In Tamara Borgoiakova (ed.), Razvitie iazykov i kultur korennykh narodov Sibiri v usloviiakh izmeniaiushcheisia Rossii [Development of languages and cultures of indigenous peoples of Siberia in changing Russia]. Abakan, 54-58.

Borgoiakova, T.G. (2015). Language policies and language loyalties after twenty years in post-Soviet Russia: The case of Khakassia. In Christel Stolz (ed.), Language Empires in Comparative Perspective, 141-151.

Borgoiakova, T.G., Guseinova, A.V. (2012). Demograficheskaia moshchnost' khakasskogo iazyka i iazykovaia loialnost' zhitelei Khakasii [Khakass Language Demographic Power and Language Loyalties of the population of Khakassia]. In Mir nauki, kultury, obrazovaniia [The world of science, culture and education], 5 (36), 233-237.

Borgoiakova, T.G., Guseinova, A.V. (2017). Status i funktsionirovanie tiurkskikh iazykov Iuzhnoi Sibiri [Status and functioning of Turcic languages of Soutern Siberia]. Abakan, Izdatelstvo Khakasskogo gosudarstvennogo universiteta im. N. F. Katanova, $136 \mathrm{p}$.

Bowring B. (2012). Russian legislation in the area of minority rights. In O. Protsyk and B. Harzl (eds.) Managing Ethnic Diversity in Russia, 15-36.

Crystal, D. (1992). An encyclopedic dictionary of language and languages. Cambridge, MA: Blackwell, 428 p.

Dorina, G. (2014). Nemeckii i francuzskii iazyki v sisteme vysshego filologicheskogo obrazovaniia Khakasii [German and French in the system of higher philological education of Khakassia]. In Vestnik Khakasskogo gosudarstvennogo universiteta im. N.F. Katanova [Bulletin of Katanov Khakass State University], 7, 131-135. 
Federal state statistics service (2010). All-Russia population census 2010. Available at: http://www.gks.ru/free_doc/new_site/perepis2010/croc/perepis_itogi1612.htm (accessed 25 February 2019)

Federal'nye gosudarstvennye obrazovatel'nye standarty [Federal State Educational Standards] (2009). Available at: https://fgos.ru/ (accessed 25 February 2019)

Felde, O.V., Kolmogorova, A.V., Zhuravel, T.N. (2017). The Current Situation and the Future of the Tuvan Language in Krasnoyarsk Region: Ethnopsycholinguistic Survey Results. In Journal of Siberian Federal University. Humanities \& Social Sciences, 1, 16-24.

Garipov, Y., Solnyshkina, M. (2006). Language Reforms in Tatarstan's Education System and the Ethnoliguistic Orientation of Young People. In Donall O'Riagain (ed.), Voces Diversae: Lesser Used Language Education in Europe, 131-137.

Goryacheva, M. (2010). Rossiiskaia Federatsiia: funktsionirovanie iazykov $v$ sovremennom obrazovatel'nom prostranstve [Russian Federation: language functioning in the modern educational space]. Moscow, Noviy khronograf, $272 \mathrm{p}$.

Kaplan, R.B., Baldauf, R.B. (1997). Language planning from practice to theory. Clevedon: Multilingual Matters, $404 \mathrm{p}$.

Konstitutsiia Rossiiskoi Federatsii [Constitution of the Russian Federation] (1993). Avalible at: http://www.consultant.ru/document/cons_doc_LAW_28399/(accessed 25 February 2019).

Kutyaeva, O. (2014). Istoriia iazykovogo obrazovaniia v Khakasii: opyt kafedry angliiskoi filologii i teorii iazyka [The history of language education in Khakassia: the experience of the Department of English Philology and linguistuics]. In Vestnik Khakasskogo gosudarstvennogo universiteta im. N. F. Katanova [Bulletin of Katanov Khakass State University], 7, 135-137.

McCarty, T.L. (2011). Introducting Ethnography and Language Policy. In Teresa L. McCarty (ed.), Ethnography and Language Policy, 1-28.

Moseley, C. (2010). Atlas of the World's Languages in Danger, 3rd edn. Paris, UNESCO Publishing. Available at: http://www.unesco.org/languages-atlas/ (accessed 25 February 2019)

Spolsky, B. (2017). Language Policy in Education: Practices, Ideology, and Management. In Teresa McCarty and Stephen May (eds.), Language Policy and Political Issues in Education, Encyclopedia of Language and Education. DOI: 10.1007/978-3-319-02320-5_1-1

Zakon o Iazykakh Narodov Rossiiskoi Federatsii [Law on the Languages of the Peoples of the Russian Federation] (1991). Avalible at: http://www.consultant.ru/ document/cons_doc_LAW_15524/(accessed 25 February 2019) 


\title{
Языковая политика \\ в сфере университетского образования \\ Хакасии и Тувы
}

\author{
Т.Г. Боргоякова, А. В. Гусейнова \\ Хакасский государственный университет \\ имени Н. Ф. Катанова \\ Россия, 655017, Абакан, ул. Ленина 90
}

\begin{abstract}
В статье рассматриваются особенности макро- и микроязыковой политики в языковом образовании южносибирских республик Тыва и Хакасия, которое включает русский, иностранные, а также языки коренных народов - тувинский и хакасский, имеющие статус республиканских государственных языков. Сравнительное изучение неязыковых образовательных программ различного уровня в Хакасском государственном университете и Тувинском государственном университете позволило оценить лингвистический «вес» учебных программ бакалавриата и выявить более очевидную лингвистическую направленность в Тувинском государственном университете. Безусловным лидером среди иностранных языков, изучаемых в двух университетах, является английский, на втором месте - немечкий. Сочиолингвистические опросы студентов разной этнической принадлежности позволили установить уровни самооценки их языковой компетениии на иностранных и родных языках. Почти треть респондентов оченивают качество владения иностранными языками как неудовлетворительное, что связано со слабой школьной языковой подготовкой и минимальными перспективами учебы и трудоустройства за рубежом. Самооценка уровня владения этническими языками существенно выше - только $18 \%$ хакасских респондентов не владеют родным языком. Однако тувинский и хакасский языки, включенные в Атлас исчезающих языков ЮНЕСКО, практически не представлены в программах университетского нелингвистического образования. Введение обязательного ЕГЭ по русскому и иностранным языкам оказывает негативное влияние на позиции республиканских государственных языков, что усиливает роль языкового планирования и его субъектов на микроуровне.
\end{abstract}

Ключевые слова: языковое планирование, языковая политика, языковое образование, Тыва, Хакасия.

Научная специальность: 10.00.00 - филологические науки. 